\title{
CO-DIGESTION OF POULTRY MANURE WITH MIXTURE OF COFFEE, CASSAVA AND COCONUT WASTES
}

\author{
F. ABOUELENIEN ${ }^{1}$ and Y. NAKASHIMADA ${ }^{2}$ \\ ${ }^{1}$ Department of Hygiene and Preventive Medicine, Faculty of Vet Med, Kafer Elshikh University, Egypt \\ ${ }^{2}$ Department of Molecular Biotechnology, Graduate School of Advanced Sciences of Matter, Hiroshima University, \\ Kagamiyama 1-3-1, Higashi- Hiroshima, 739-8530, Japan
}

Received: 8 November 2015; Accepted: 15 November 2015

\begin{abstract}
This study was conducted to test the effect on thermophilic and mesophilic digestion of poultry manure (PM) or treated poultry manure (TPM) by the addition of agriculture wastes (AWS) as a co-substrate under dry conditions. PM was co-digested with a mixture of AWS consisting of coconut waste, cassava waste, and coffee grounds. Obtained results revealed increased methane content in biogas, with decrease ammonia accumulation and volatile acids (VFA). The highest performance occurred under mesophilic conditions, with a $63 \%$ and $41.3 \%$ increase in methane production from addition of AWS to TPM $\left(562 \mathrm{ml} \mathrm{g} \mathrm{VS}^{-1}\right.$ vs. $344 \mathrm{ml} \mathrm{g} \mathrm{VS}^{-1}$ from control) and PM (406 ml g VS ${ }^{-1}$ vs. $287 \mathrm{ml} \mathrm{g} \mathrm{VS}^{-1}$ from control), respectively. Thermophilic conditions showed lower performance than mesophilic conditions. Addition of AWS increased methane production by $150 \%$ and $69.6 \%$ from PM (323.4 ml g VS${ }^{-1}$ vs. $129 \mathrm{ml} \mathrm{g} \mathrm{VS}^{-1}$ from control), and TPM (297.6ml g VS${ }^{-1}$ vs. $175.5 \mathrm{ml} \mathrm{g} \mathrm{VS}^{-1}$ from control), respectively. In all experiments, $100 \%$ acetate produced was degraded to methane. Maximum ammonia accumulation was lowered to $43.7 \%$ by mixing of AWS (range $5.35-8.55 \mathrm{~g} \mathrm{~N} / \mathrm{kg}^{-1}$ bed vs. $7.81-12.28 \mathrm{~g} \mathrm{~N} / \mathrm{kg}^{-1}$ bed). The $\mathrm{pH}$ was held at 7.3-8.8, a range suitable for methanogenesis.
\end{abstract}

Keywords: Dry Co-digestion, Methane production, Poultry manure, Coffee waste, Cassava waste, coconut waste

\section{INTRODUCTION}

Recently, there has been considerable interest concerning the use of livestock manure as an alternative renewable source of energy. This is due in part to the continuous economic and environmental concerns facing farmers and governments (Ragauskas et al., 2006). Anaerobic digestion (AD) is considered to be an important and advantageous process in livestock manure waste treatment. It converts plant biomass, crop residues, animal manures, and other organic wastes into methane-rich biogas, a widely used source of renewable energy, while reducing the environmental hazard of livestock waste (Wang et al., 2012).

AD is usually classified as wet, semi-solid, or solid state, referring to total solids (TS) of substrate percentages of $<10 \%, 10-15 \%$, or $>15 \%$, respectively (Li et al., 2011). Of these, dry anaerobic digestion has

Corresponding author: F. ABOUELENIEN

E-mail address: fabou2ga@yahoo.com

Present address: Department of Hygiene and Preventive Medicine, Faculty of Vet Med, Kafer Elshikh University, Egypt several benefits over conventional wet anaerobic digestion (Zhou et al., 2011), including reduction of the reactor volume, high volumetric methane productivity, low energy requirements for heating, positive energy balance, and less wastewater, as well as an end product of more easily transportable fertilizer (Li et al., 2013; Schafer et al., 2006). Thus, dry anaerobic digestion of high solid content feedstock has shown continuous growth (Brown and Li, 2013; Brown et al., 2012; Xu and Li, 2012). However, while the wet or semi-dry digestion process of animal manure is an established method and has been widely studied (Nishio and Nakashimada, 2007), very few studies have been conducted on the $\mathrm{AD}$ of poultry manure $(\mathrm{PM})$, especially in a solid state or dry condition (Abouelenien et al., 2009a, b; 2010; Demeirci and Demirer, 2004).

An excess of either nitrogen or carbon content could lead to process inhibition (Forster-Carneiro et al., 2007). High ammonia content derived from organic nitrogen in PM under dry conditions makes this substrate difficult to digest anaerobically (Borowski and Weatherley, 2013). Several researchers have investigated the inhibitory effect of ammonia during 
anaerobic digestion of animal wastes (Bruni et al., 2013; calli et al., 2005). Many studies have focused on reducing the inhibitory effect of ammonia and volatile fatty acids (VFA) to improve the fermentation of PM for the production of methane. In a study, PM was diluted with water to decrease the total percentage of solid (Karaalp et al., 2013). Ammonia removal has also been attempted by different researchers in the effort to enhance methane fermentation (Abouelenien et al., 2010). However, the reported removal methods also necessitated decreasing the TS\% through dilution with water, resulting in an increase in waste volume. Chemicals were also needed to remove ammonia, thus increasing cost.

An alternative method for dry AD of PM is codigestion. It offers several benefits including: increased biogas production resulting from increased loading of readily biodegradable organics, improved balance of nutrients and $\mathrm{C} / \mathrm{N}$ ratio, dilution of toxic substances including ammonia without the addition of water and expensive chemicals, a better quality of a digested product, and reduced costs from processing several substrates in one installation (Khalid et al., 2011; Wang et al., 2012; 2013). Actually, Borowski and Weatherley, (2013) showed that $30 \%$ addition of PM to sewage sludge increased total gas production by $50 \%$. There are many examples of co-digestion of PM, and other research has shown positive results with other types of livestock waste, including cattle manure (Demeirci and Demirer, 2004), hog wastes (Magbanua et al., 2001), anaerobically digested sludge (ADS) (Bujoczek et al., 2000), fruit and vegetable wastes (FVW), cattle slurries (Callaghan et al., 2002), buffalo manure with OFMSW (Esposito et al., 2012), and a mixture containing $40 \%$ dairy manure, $40 \%$ PM and 20\% wheat straw (Wang et al., 2012). It may therefore be said that co-digestion of $\mathrm{PM}$ with different waste materials is an effective way to reduce the ammonia derived from PM and increase biogas production. However, feed stocks co-digested with PM need to be restricted based on their $\mathrm{C} / \mathrm{N}$ ratio, and the supplied amount balanced with that of PM. Agriculture wastes with low $\mathrm{C} / \mathrm{N}$ ratio are thus promising candidates, because increased methane yield and biodegradation rate by co-digestion of PM and agriculture wastes will result in more methane generation per unit fed mass and reduce the size of the reactor required, which makes the process more attractive economically (Wall et al., 2012).

Coffee is the second largest traded commodity in the world, and its processing generates large amounts of by-products and residues. Although wastes and byproducts produced during coffee berry processing constitute a source of severe contamination and pose serious environmental threats in coffee-producing countries, reports on anaerobic digestion of coffee wastes are limited (Corro et al., 2013). Coconut and cassava wastes have a high energy potential and a large amount of it is exhaust. They could be used as a co-substrate for anaerobic digestion (Alvarez and Liden, 2007; Panichnumsin et al., 2010). However, previously reported experiments on co-digestion of PM and other feed stocks have been carried out under diluted conditions with high water content and low ammonia concentration.

To the best of our knowledge, this study is the first to investigate the mixture of agriculture wastes (AWS) consisting of coconut, cassava wastes and coffee ground as a co-substrate with PM. One previous study attempted co-digestion of the mixture described above under semi-solid condition with TS of $10 \%$ and 93\% increase in methane production (Abouelenien et al., 2014). The main goal of this study was to evaluate the effect of agricultural wastes added as a co-substrate on performance of anaerobic digestion under dry conditions (TS 20\%). Both mesophilic (35 $\left.\pm 2^{\circ} \mathrm{C}\right)$ and thermophilic $\left(55 \pm 2^{\circ} \mathrm{C}\right)$ fermentation condition were used and compared. Methane production, ammonia accumulation, and acetate degradation were used as evaluation parameters.

\section{MATERIALS and METHODS}

1. Substrates and seed sludge used for anaerobic co-digestion processes

Fresh poultry manure (PM) from Hiroshima University Poultry farm (cage layer system) was collected from deposits directly under chicken cages. PM had the following characteristics: $25 \%$ (W/W) TS, $69.8 \%$ TS of VS, $380 \mathrm{~g}-\mathrm{C} \mathrm{kg-TS}{ }^{-1}$ total organic carbon (TOC), $87 \mathrm{~g}-\mathrm{N} \mathrm{kg-TS}{ }^{-1}$ total kjeldahl nitrogen (TKN), and 26.5 g-N kg-TS ${ }^{-1}$ total ammonia nitrogen (TAN). Treated PM (TPM) was produced by stripping ammonia from PM using the technique described in Abouelenien et al. (2010). TPM was characterized as $20 \%$ (W/W) TS, $70.3 \%$ TS of VS, $85.5 \mathrm{~g}-\mathrm{N} \mathrm{kg-TS}^{-1}$ of TKN, and $10.5 \mathrm{~g}-\mathrm{N} \mathrm{kg-TS}{ }^{-1}$ of TAN. Agriculture wastes (AWS), consisting of a mixture of cassava (root residue wet cake), coconut (wet cake) and coffee ground waste, was shipped frozen from Thailand and received by Hitachi Engineering a Services-Japan (HES-TH). Characteristics of the AWS are presented in Table 1. The seed sludge collected from a Waste water Treatment Center in Hiroshima, Japan, was anaerobically incubated at $55{ }^{\circ} \mathrm{C}$ for 60 days in the laboratory in order to achieve complete consumption of the substrate. The seed sludge was characterized as $20 \%$ (W/W) TS, $53 \%$ TS of VS, $268 \mathrm{~g}-\mathrm{C} \mathrm{kg-TS}{ }^{-1}$ of TOC, $3.2 \mathrm{~g}-\mathrm{N} \mathrm{kg-TS}{ }^{-1}$ of $\mathrm{TKN}$, and $3.2 \mathrm{~g}-\mathrm{N} \mathrm{kg-TS}{ }^{-1}$ of TAN. All samples were collected in triplicate, and the averages of the three measurements are presented.

2. Experimental setup and procedures 
2.1. Experiment 1 (Exp 1) dry (20\%) anaerobic codigestion of PM and AWS with repeated batch culture

The substrates consisted of PM, mixed with AWS and inoculated with seed sludge. Water was added to adjust TS to $20 \%$, so that the ratio of PM to AWS was 7:3 (not controlled). Ratio of inoculum (Ozu sludge) to substrate (PM+AWS) was kept 3:1(V/V). The substrate was placed in a set of $500 \mathrm{ml}$ capacity anaerobic vials, $200 \mathrm{~g}$ of each (Mixture 1 (M1)). As control, vials without AWS supplement were used (PM control). The head space in the vials was purged with N2 gas, and sealed with rubber stoppers in crimped aluminum caps. These bottles were incubated anaerobically at $35 \pm 2{ }^{\circ} \mathrm{C}$ (mesophilic condition) or $55 \pm 2{ }^{\circ} \mathrm{C}$ (thermophilic condition). Semi-continuous batch culture was used for these codigestion. Triplicate vials for each condition was used. The amounts, composition and conditions of anaerobic digestion of these substrates and cosubstrate are illustrated in Table 3.

2.2. Experiment 2 (Exp 2) dry (20\%) anaerobic codigestion of TPM and AWS with repeated batch culture.

The treatment procedures of TPM and PM (Mixture 2 (M2)) were carried out identically, which was described in section 2.2.1.

The amounts, composition and conditions of anaerobic digestion of these substrates and cosubstrate are illustrated in Table 4.

\section{Analytical methods}

Volumes of gases and their composition were monitored every day. When gas production stopped, vials were opened, and samples were taken to measure the produced ammonia, volatile fatty acids (VFAs) and pH. For the next step of the new batch culture, half of the vial contents were removed, and the vials were replenished with the same amount of substrate. This procedure for batch culture was repeated for 3 batches and was conducted over a total duration of 114 days. Duration of the first batch was 40 days, second batch- 35 days, the third batch -39 days.

Fermentation samples (ca. $0.3 \mathrm{~g}$ wet weight) were withdrawn into 2-ml plastic tubes and suspended with $1.2 \mathrm{ml}$ deionized water. The suspension was centrifuged at 3,000 $\mathrm{rpm}$ for $10 \mathrm{~min}$ at $4{ }^{\circ} \mathrm{C}$, and the clear supernatant was used for measurement of $\mathrm{pH}$, ammonia, and Volatile fatty acids (VFAs). VFAs were measured using a High Performance Liquid Chromatograph (Shimadzu, Kyoto, Japan) equipped with Aminex HPX-87H Column, 300mm x 7.8mm (Bio-Rad, Tokyo, Japan). The column temperature was $65^{\circ} \mathrm{C}$. The flow rate was $0.8 \mathrm{ml} \mathrm{min}^{-1}$ for 0.005
$\mathrm{M} \mathrm{H}_{2} \mathrm{SO}_{4}$ solution, used as a mobile phase. Ammonia was measured using a commercially available ammonia testing kit (Wako Ltd., Osaka, Japan). TOC was determined with a TOC analyzer (TOC-5000, Shimadzu). TS, VS, TKN, and $\mathrm{pH}$ were measured in accordance with the standard methods (APHA, 1998). Soluble carbohydrate concentration was measured by the phenol sulfuric acid method, with glucose as standard (Dubois et al., 1956). Soluble protein was determined by the Lowry-Folin method, with bovine serum albumin as the standard (Lowry et al., 1951). The lipid content was analyzed by Soxhlet with petroleum ether extraction according to AOAC methods (AOAC, 1995).

Gas production was measured periodically by displacement of saturated aqueous $\mathrm{NaCl}$ in a graduated cylinder. The composition of $\mathrm{CH}_{4}, \mathrm{H}_{2}$, and $\mathrm{CO}_{2}$ was determined by a gas chromatograph (GC-8A, Shimadzu) with a thermal conductivity detector equipped with a glass column $(2 \mathrm{~m} \times 3 \mathrm{~mm})$ packed with unibeads $\mathrm{C} 60 / 80$ (Shimadzu) at $140{ }^{\circ} \mathrm{C}$. Argon was used as the carrier gas at a pressure of $100 \mathrm{kPa}$. All samples were collected in triplicate, and the averages of the three measurements are presented.

\section{RESULTS}

1. Characteristics of substrate

Two experiments were conducted (Exp 1 and Exp 2); substrate characteristics, components, and contents/ concentrations of PM, TPM, and AWS for both are presented in Tables 1 and 2. On a dry matter (TS) basis, AWS contained higher volatile solids (VS) but lower fixed solids (FS) than PM. The higher VS content of AWS (98.7\%) compared with that of manure $(70 \%)$ means higher energy content, which is desirable economically with regard to both transportation and biogas energy production. The initial $\mathrm{pH}$ of the AWS was 4.85, while it was 8.5 and 7.75 for PM and TPM, respectively.

\section{Methane production}

The cumulative methane profile of dry anaerobic codigestion from Exps 1 and 2 is shown in Fig. 1. The substrate was composed of PM or TPM mixed with AWs and inoculated with seed sludge at a ratio of (1:3); control vials of PM or TPM with no added AWS were also used. Semi-continuous batch culture was used for the co-digestion. As already mentioned, three batches were carried out, the first for 40 days, the second for 35 days, and the third for 39 days for a total length of each experiment of 114 days. Thermophilic $\left(55 \pm 2{ }^{\circ} \mathrm{C}\right)$ and mesophilic $\left(35 \pm 2{ }^{\circ} \mathrm{C}\right)$ conditions were used in both experiments.

Fig. 1(a) shows that in Exp 1 under thermophilic conditions $\left(55 \pm 2{ }^{\circ} \mathrm{C}\right)$, co-digestion of PM with AWS (M1) increased methane production by $150 \%$ over the 
control (maximum production of $323.4 \mathrm{ml} \mathrm{g}^{-1} \mathrm{VS}$ vs. $\left.129 \mathrm{ml} \mathrm{g}^{-1} \mathrm{VS}\right)$. Complete inhibition of methane production was reported in PM control at 2nd and 3rd batches. A maximum of $195 \%$ increase in methane production resulted from M1 under the mesophilic $\left(35 \pm 2^{\circ} \mathrm{C}\right)$ condition (highest amount of methane produced was $406 \mathrm{ml} \mathrm{g}^{-1} \mathrm{VS}$ vs. $136.9 \mathrm{ml} \mathrm{g}^{-1} \mathrm{VS}$ from PM control). Complete inhibition of methane production was observed in the 3rd batch with PM control.

Fig. 1(b) shows the methane profile of Exp 2 under thermophilic conditions; there was a $70 \%$ increase in methane production from M2 compared with TPM control (297.6 $\mathrm{ml} \mathrm{g}^{-1} \mathrm{VS}$ vs. $\left.175.4 \mathrm{ml} \mathrm{g}^{-1} \mathrm{VS}\right)$. In the 3rd batch, methane production was totally inhibited in TPM control. On the other hand, co-digestion of M2 under mesophilic conditions $\left(35 \pm 2^{\circ} \mathrm{C}\right)$ resulted in $63 \%$ as a maximum increase in methane production from M2 over TPM control. Maximum methane produced was $562 \mathrm{ml} \mathrm{g}^{-1}$ VS from M2 vs. $344 \mathrm{ml} \mathrm{g}^{-1}$ VS from TPM control.

3. VFAs (Acetate) production/degradation, $\mathrm{pH}$ and ammonia

Table 4 illustrates the course of acetate production/degradation under both thermophilic and mesophilic conditions in Exps 1 and 2. In Exp 1, under thermophilic conditions, acetate was accumulated in both PM control and M1 (2nd and 3rd batches) with a maximum of $286 \mathrm{mM} \mathrm{kg}^{-1}$ bed accumulated in PM control. Meanwhile, $77.8 \%$ of the resulting acetate was degraded with $\mathrm{M} 1$ in the 1 st batch (table 4). In Exp 2, TPM control and M2 (2nd and $3 \mathrm{rd}$ batches), at $55^{\circ} \mathrm{C}$, acetate accumulated to reach a maximum of $290 \mathrm{mM} \mathrm{kg}^{-1}$ bed, while $31 \%$ of acetate produced was degraded in $1^{\text {st }}$ batch of M2. In contrast, in Exp 1, M1 under $35{ }^{\circ} \mathrm{C}$ acetate was degraded by $86 \%, 100 \%$, and $87 \%$ in the 1 st, 2 nd and 3rd batches respectively (table 4). Mesophilic conditions of Exp 2 TPM control showed 97\%, 67\%, and $5.2 \%$ degradation of acetate in the $1 \mathrm{st}$, 2nd and 3rd batches. Finally, the best acetate degradation was observed with M2 under the mesophilic condition, which showed almost $100 \%$ acetate degradation in all batches (table 4).
Table 5 shows that in both Exps 1 and 2, pH changed according to the degree of acetate degradation. Initial $\mathrm{pH}$ for all mixtures ranged from $7.3-8$, then $\mathrm{pH}$ was increased by degradation of acetate and production of methane. In both experiments, $\mathrm{pH}$ increased to a range of $8.1-8.6$ by the end of the experiments. In addition, a clear drop in $\mathrm{pH}$ values was observed under thermophilic conditions in both experiments.

Table 6 illustrates that ammonia production increased gradually from the 1st batch to the end of the 3rd batch under all conditions in both experiments. Table 6 shows that initial ammonia values were 1.8 and 1.3 $\mathrm{g}-\mathrm{N} \mathrm{kg}{ }^{-1}$ bed in the Exp 1 PM control and M1, respectively, under both mesophilic and thermophilic conditions. Under $55^{\circ} \mathrm{C}$, ammonia was accumulated until it reached 12.3 and $7.4 \mathrm{~g} \mathrm{~N} \mathrm{~kg}^{-1}$ bed at the end of the 3rd batch of the Exp 1 PM control and M1, respectively, while under $35{ }^{\circ} \mathrm{C}$, ammonia values were 8.2 and $5.4 \mathrm{~g} \mathrm{~N} \mathrm{~kg}^{-1}$ bed, respectively. Under the thermophilic condition, a 39\% decrease in ammonia accumulation was found with M1 compared to PM control, while a $34 \%$ decrease was achieved in M1 under the mesophilic condition. The ammonia profile of Exp 2 illustrated in table 6 shows that initial ammonia values in the bed were 1.04 and $1.2 \mathrm{~g}-\mathrm{N} \mathrm{kg}^{-}$ ${ }^{1}$ bed in the Exp 2 TPM control and M2, respectively, under both mesophilic and thermophilic conditions. In TPM control, ammonia was accumulated until it reached 7.18 and $10.2 \mathrm{~g} \mathrm{~N} / \mathrm{kg}$ bed at the end of the $3 \mathrm{rd}$ batch, at $35{ }^{\circ} \mathrm{C}$ and $55{ }^{\circ} \mathrm{C}$ respectively, while a 6.06 and $8.5 \mathrm{~g} \mathrm{~N} / \mathrm{kg}$ bed was accumulated at the end of the 3rd batch from $\mathrm{M} 2$ under $35{ }^{\circ} \mathrm{C}$ and $55{ }^{\circ} \mathrm{C}$ respectively. Addition of AWS resulted in decreased ammonia accumulation by $16 \%$ and $24 \%$ at $35{ }^{\circ} \mathrm{C}$ and $55^{\circ} \mathrm{C}$, respectively.

\section{FIGURE CAPTION}

Fig.1 Methane production from dry anaerobic codigestion (20\% TS) by repeated batch culture of: a) Exp 1: PM only (PM control), or co-digested with AWs (M1); b) Exp 2: digestion of treated poultry manure (TPM) only (TPM control), or mixed with AWs (M2). Seed sludge was used as inoculum. Fermentation temperatures were $35{ }^{\circ} \mathrm{C}$ (mesophilic) and $55{ }^{\circ} \mathrm{C}$ (thermophilic). Duration of batch I, 40 days; batch II, 35 days; batch III, 39 days. 


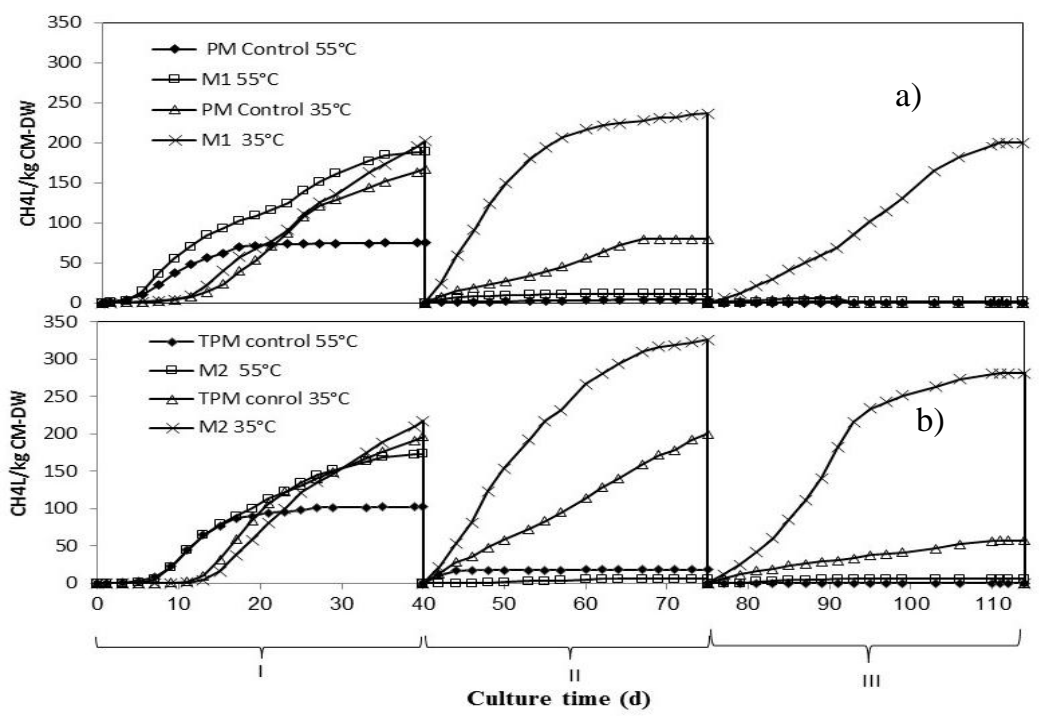

Fig.1 Methane production from dry anaerobic co-digestion (20\% TS) by repeated batch culture of: a) Exp 1: poultry manure (PM) only (PM control); or co-digested with AWs (M1). b) Exp 2: Digestion of treated poultry manure (TPM)) only (TPM control) or mixed with AWs (M2). Seed sludge was used as inoculum. Fermentation temperatures were $35^{\circ} \mathrm{C}$ (mesophilic) and $55{ }^{\circ} \mathrm{C}$ (thermophilic). Duration of batch I, $40 \mathrm{~d}$; batch II, $35 \mathrm{~d}$; batch III, $39 \mathrm{~d}$.

Table 1: Characteristics of agriculture wastes (AWS). TS total solids, VS volatile solids, T-COD Total chemical oxygen demand

\begin{tabular}{lcccc}
\hline Item & Unit & Coconut & Coffee ground & Cassava \\
\hline TS & $\%$ & 40.58 & 20.48 & 19.60 \\
\hline VS & $\%$ & 98.87 & 99.16 & 19.40 \\
\hline Moisture content & $\%$ & 59.42 & 79.52 & 72.00 \\
\hline T-COD & $\mathrm{mg} / \mathrm{L}$ & 1444 & 1631 & 257,000 \\
\hline Carbohydrate & $\mathrm{mg} / \mathrm{L}$ & 7797 & 25,513 & 87,400 \\
\hline Protein & $\mathrm{mg} / \mathrm{L}$ & 2100 & 88,020 & 50,800 \\
\hline Lipid & $\mathrm{mg} / \mathrm{L}$ & 10,524 & 260,626 & 22,300 \\
\hline
\end{tabular}

Table 2: Experiment 1: Dry anaerobic co-digestion of PM and AWs with 20\% TS by repeated batch culture.

\begin{tabular}{|c|c|c|c|c|}
\hline \multirow[b]{2}{*}{ Item } & \multicolumn{2}{|c|}{ Amount (g) } & \multicolumn{2}{|l|}{ Percentage $(\%)$} \\
\hline & $\begin{array}{c}\text { Mixture } 1 \\
(\mathrm{M} 1)\end{array}$ & $\begin{array}{c}\text { Poultry manure } \\
\text { (PM control) }\end{array}$ & $\begin{array}{c}\text { Mixture 1 } \\
(\mathrm{M} 1)\end{array}$ & $\begin{array}{l}\text { Poultry manure } \\
(\mathrm{PM})\end{array}$ \\
\hline $\mathrm{PM}$ & 28 & 40 & 14 & 20 \\
\hline Ozouh sludge & 150 & 150 & 75 & 75 \\
\hline Coconut & 2.1 & 0 & 1.05 & 0 \\
\hline Coffee ground & 5 & 0 & 2.5 & 0 \\
\hline Cassava & 1.3 & 0 & 0.65 & 0 \\
\hline Added water & 13.6 & 10 & 6.8 & 5 \\
\hline Total & 200 & 200 & 100 & 100 \\
\hline
\end{tabular}

Table 3: Experiment 2: Dry anaerobic co-digestion of TPM and AWs with $20 \%$ TS by repeated batch culture.

\begin{tabular}{lcccc}
\hline Item & Amount $(\mathrm{g})$ & \multicolumn{3}{c}{ Percentage (\%) } \\
\cline { 2 - 5 } & $\begin{array}{c}\text { Mixture } 2 \\
(\mathrm{M} 2)\end{array}$ & $\begin{array}{c}\text { Treated Poultry } \\
\text { manure (TPM control) }\end{array}$ & $\begin{array}{c}\text { Mixture 2 } \\
(\mathrm{M} 2)\end{array}$ & $\begin{array}{c}\text { Treated Poultry } \\
\text { manure (TPM) }\end{array}$ \\
\hline TPM & 35 & 50 & 17.5 & 25 \\
\hline Ozouh sludge & 150 & 150 & 75 & 75 \\
\hline Coconut & 2.1 & 0 & 1.05 & 0 \\
\hline Coffee ground & 5 & 0 & 2.5 & 0 \\
\hline Cassava & 1.3 & 0 & 0.65 & 0 \\
\hline Added water & 6.6 & 0 & 3.3 & 100 \\
\hline Total & 200 & 200 & 100 & 0 \\
\hline
\end{tabular}


Table 4: Acetate (mM/kg-bed) production and degradation during dry anaerobic co-digestion (20\% TS) by repeated batch culture.

\begin{tabular}{|c|c|c|c|c|c|c|c|c|c|c|c|c|c|c|c|c|}
\hline \multirow{3}{*}{$\begin{array}{c}\text { Batch } \\
\text { No. }\end{array}$} & \multicolumn{8}{|c|}{ Exp.1 } & \multicolumn{8}{|c|}{ Exp.2 } \\
\hline & \multicolumn{2}{|c|}{$\begin{array}{c}\text { PM } \\
\text { Control 55 }^{\circ} \mathrm{C}\end{array}$} & \multicolumn{2}{|c|}{ M1 55 ${ }^{\circ} \mathrm{C}$} & \multicolumn{2}{|c|}{$\begin{array}{c}\text { PM } \\
\text { Control } 35^{\circ} \mathrm{C} \\
\end{array}$} & \multicolumn{2}{|c|}{ M1 $35^{\circ} \mathrm{C}$} & \multicolumn{2}{|c|}{$\begin{array}{c}\text { TPM } \\
\text { Control } 55^{\circ} \mathrm{C} \\
\end{array}$} & \multicolumn{2}{|c|}{$\begin{array}{c}\mathbf{M} 2 \\
55^{\circ} \mathrm{C}\end{array}$} & \multicolumn{2}{|c|}{$\begin{array}{c}\text { TPM } \\
\text { Control } 35^{\circ} \mathrm{C} \\
\end{array}$} & \multicolumn{2}{|c|}{ M2 $35^{\circ} \mathrm{C}$} \\
\hline & Intial & final & Intial & final & Intial & final & Intial & final & Intial & final & ntial & Final & Intial & Final & Intial & Final \\
\hline I & $\begin{array}{l}75 \pm \\
7.6 \\
\end{array}$ & $\begin{array}{c}144.93 \pm \\
15.9 \\
\end{array}$ & $\begin{array}{c}56.71 \pm \\
4.5 \\
\end{array}$ & $\begin{array}{c}12.6 \pm \\
1.1 \\
\end{array}$ & $\begin{array}{l}75 \pm \\
6.8 \\
\end{array}$ & $\begin{array}{c}6.1 \pm \\
0.6 \\
\end{array}$ & $\begin{array}{c}56.71 \pm \\
5.1 \\
\end{array}$ & $\begin{array}{c}7.72 \pm \\
0.7 \\
\end{array}$ & $\begin{array}{c}60.23 \pm \\
5.4 \\
\end{array}$ & $\begin{array}{c}123.29 \pm \\
13.6 \\
\end{array}$ & $\begin{array}{c}68.99 \pm \\
8.3 \\
\end{array}$ & $\begin{array}{c}47.41 \pm \\
4.7 \\
\end{array}$ & $\begin{array}{c}60.23 \pm \\
5.4 \\
\end{array}$ & $\begin{array}{c}1.85 \pm \\
0.2 \\
\end{array}$ & $\begin{array}{c}68.99 \pm \\
6.2 \\
\end{array}$ & $\begin{array}{c}6.01 \pm \\
0.5 \\
\end{array}$ \\
\hline II & $\begin{array}{c}226.2 \pm \\
22.7\end{array}$ & $\begin{array}{l}234 \pm \\
21.1\end{array}$ & $\begin{array}{c}93.7 \pm \\
9.4\end{array}$ & $\begin{array}{r}156 \pm \\
15.6\end{array}$ & $\begin{array}{l}84 \pm \\
9.2\end{array}$ & $\begin{array}{c}115 \pm \\
12.7\end{array}$ & $\begin{array}{c}91.8 \pm \\
10.1\end{array}$ & ND & $\begin{array}{c}124.7 \pm \\
14.9\end{array}$ & $\begin{aligned} & 242 \pm \\
& 21.8\end{aligned}$ & $\begin{array}{c}138.8 \pm \\
12.5\end{array}$ & $\begin{array}{l}236 \pm \\
28.3\end{array}$ & $\begin{array}{c}137.6 \pm \\
15.1\end{array}$ & $\begin{array}{c}45.5 \pm \\
5.5\end{array}$ & $\begin{array}{c}67.9 \pm \\
8.1\end{array}$ & ND \\
\hline III & $\begin{array}{c}173.5 \pm \\
15.6\end{array}$ & $\begin{array}{c}285.8 \pm \\
34.3\end{array}$ & $\begin{array}{r}138 \pm \\
15.2\end{array}$ & $\begin{array}{c}199.8 \pm \\
23.9\end{array}$ & $\begin{array}{c}126 \pm \\
10\end{array}$ & $\begin{array}{l}132 \pm \\
15.8\end{array}$ & $\begin{array}{l}54 \pm \\
4.3\end{array}$ & $\begin{array}{c}7.15 \pm \\
0.6\end{array}$ & $\begin{array}{c}278 \pm \\
30.6\end{array}$ & $\begin{array}{c}290.25 \pm \\
34.8\end{array}$ & $\begin{array}{l}195 \pm \\
21.5\end{array}$ & $\begin{array}{c}275.75 \pm \\
33.1\end{array}$ & $\begin{array}{l}116 \pm \\
10.4\end{array}$ & $\begin{array}{c}110.33 \pm \\
13.2\end{array}$ & $\begin{array}{l}87 \pm \\
8.7\end{array}$ & $\begin{array}{c}0.27 \pm \\
0.03\end{array}$ \\
\hline
\end{tabular}

Initial: values at the beginning of each batch

Final: values at the end of each batch

Exp 1: poultry manure (PM) only (PM control); or co-digested with AWs (M1). Exp 2: Digestion of treated poultry manure

(TPM)) only (TPM control) or mixed with AWs (M2).

Seed sludge was used as inoculum.

Fermentation temperatures were $35^{\circ} \mathrm{C}$ (mesophilic) and $55^{\circ} \mathrm{C}$ (thermophilic).

Duration of batch I, 40d; batch II, 35d; batch III, $39 \mathrm{~d}$.

Table 5: Initial and final changes in pH during dry anaerobic co-digestion (20\% TS) by repeated batch culture.

\begin{tabular}{|c|c|c|c|c|c|c|c|c|c|c|c|c|c|c|c|c|}
\hline \multirow{4}{*}{$\begin{array}{l}\text { Batch } \\
\text { No }\end{array}$} & \multicolumn{8}{|c|}{ Exp.1 } & \multicolumn{8}{|c|}{ Exp.2 } \\
\hline & \multirow{2}{*}{\multicolumn{2}{|c|}{$\begin{array}{c}\text { PM } \\
\text { Control } 55^{\circ} \mathrm{C}\end{array}$}} & \multirow{2}{*}{\multicolumn{2}{|c|}{ M1 $55^{\circ} \mathrm{C}$}} & \multirow{2}{*}{\multicolumn{2}{|c|}{$\begin{array}{c}\text { PM } \\
\text { Control } 35^{\circ} \mathrm{C}\end{array}$}} & \multirow{2}{*}{\multicolumn{2}{|c|}{ M1 $35^{\circ} \mathrm{C}$}} & \multirow{2}{*}{\multicolumn{2}{|c|}{$\begin{array}{c}\text { TPM } \\
\text { Control } 55^{\circ} \mathrm{C}\end{array}$}} & \multirow{2}{*}{\multicolumn{2}{|c|}{ M2 55 ${ }^{\circ} \mathrm{C}$}} & \multicolumn{2}{|c|}{ TPM } & \multirow{2}{*}{\multicolumn{2}{|c|}{ M2 $35^{\circ} \mathrm{C}$}} \\
\hline & & & & & & & & & & & & & Contre & $35^{\circ} \mathrm{C}$ & & \\
\hline & Intial & final & Intial & final & Intial & final & Intial & final & Intial & final & Intial & Final & Intial & Final & Intial & Final \\
\hline \multirow{2}{*}{$\mathbf{I}$} & 8.09 & $8.35 \pm$ & $7.85 \pm$ & $8.56 \pm$ & $8.1 \pm$ & $8.7 \pm$ & $7.85 \pm$ & $8.7 \pm$ & $7.34 \pm$ & $8.24 \pm$ & $7.33 \pm$ & $8.41 \pm$ & $7.34 \pm$ & $8.64 \pm$ & $7.33 \pm$ & $8.54 \pm$ \\
\hline & \pm 0.8 & 0.9 & 0.7 & 0.8 & 0.8 & 0.7 & 0.7 & 0.9 & 0.7 & 0.8 & 0.37 & 0.7 & 0.6 & 0.9 & 0.7 & 0.8 \\
\hline \multirow{2}{*}{ II } & 8.4 & $8.4 \pm$ & $8.3 \pm$ & $8.4 \pm$ & $8.5 \pm$ & $8.7 \pm$ & $8.4 \pm$ & $8.8 \pm$ & $8.1 \pm$ & $8.2 \pm$ & $8 \pm$ & $8 \pm$ & $8.3 \pm$ & $8.8 \pm$ & $8.2 \pm$ & $8.7 \pm$ \\
\hline & \pm 0.7 & 0.7 & 0.8 & 0.9 & 0.9 & 0.9 & 0.8 & 0.9 & 0.7 & 0.8 & 0.6 & 0.7 & 0.8 & 0.8 & 0.8 & 0.9 \\
\hline \multirow{2}{*}{ III } & $8.36 \pm$ & $8.12 \pm$ & $8.27 \pm$ & $7.69 \pm$ & $8.6 \pm$ & $8.5 \pm$ & $8.61 \pm$ & $8.81 \pm$ & $8.01 \pm$ & $7.82 \pm$ & $7.99 \pm$ & $7.34 \pm$ & $8.55 \pm$ & $8.38 \pm$ & $8.49 \pm$ & $8.64 \pm$ \\
\hline & 0.8 & 0.8 & 0.7 & 0.7 & 0.9 & 0.7 & 0.8 & 0.8 & 0.6 & 0.7 & 0.7 & 0.6 & 0.9 & 0.7 & 0.9 & 0.8 \\
\hline
\end{tabular}

Table 6: Ammonia (NH3- N g/kg bed) production during dry anaerobic co-digestion (20\% TS) by repeated batch culture

\begin{tabular}{|c|c|c|c|c|c|c|c|c|c|c|c|c|c|c|c|c|}
\hline \multirow{3}{*}{$\begin{array}{l}\text { Batch } \\
\text { No }\end{array}$} & \multicolumn{8}{|c|}{ Exp.1 } & \multicolumn{8}{|c|}{ Exp. 2} \\
\hline & \multicolumn{2}{|c|}{ 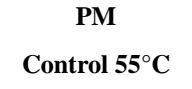 } & \multicolumn{2}{|c|}{$\mathrm{M1} 5^{\circ} \mathrm{C}$} & \multicolumn{2}{|c|}{ PM } & \multicolumn{2}{|c|}{ M1 $35^{\circ} \mathrm{C}$} & \multicolumn{2}{|c|}{$\begin{array}{c}\text { TPM } \\
\text { Control } 55^{\circ} \mathrm{C}\end{array}$} & \multicolumn{2}{|c|}{$\begin{array}{c}\text { M2 } \\
55^{\circ} \mathrm{C}\end{array}$} & \multicolumn{2}{|c|}{$\begin{array}{c}\text { TPM } \\
\text { Control } 35^{\circ} \mathrm{C}\end{array}$} & \multicolumn{2}{|c|}{$\mathrm{M} 23^{\circ} \mathrm{C}$} \\
\hline & Intial & final & Intial & final & Intial & final & Intial & final & Intial & final & Intial & Final & Intial & Final & Intial & Final \\
\hline \multirow{2}{*}{ I } & $1.75 \pm$ & $3.99 \pm$ & $1.33 \pm$ & $2.28 \pm$ & $1.8 \pm$ & $2.1 \pm$ & $1.33 \pm$ & $1.39 \pm$ & $1.04 \pm$ & $3.77 \pm$ & $1.18 \pm$ & $2.29 \pm$ & $1.04 \pm$ & $2.3 \pm$ & $1.18 \pm$ & $1.48 \pm$ \\
\hline & 0.16 & 0.39 & 0.15 & 0.17 & 0.17 & 0.17 & 0.15 & 0.16 & 0.14 & 0.37 & 0.13 & 0.17 & 0.11 & 0.17 & 0.13 & 0.17 \\
\hline \multirow{2}{*}{ II } & $6.3 \pm$ & $7.7 \pm$ & $3.4 \pm$ & $5.3 \pm$ & $3.5 \pm$ & $7.9 \pm$ & $3.4 \pm$ & $3.8 \pm$ & $3.2 \pm$ & $6.3 \pm$ & $3.3 \pm$ & $5.9 \pm$ & $3.8 \pm$ & $5.1 \pm$ & $2.3 \pm$ & $3.8 \pm$ \\
\hline & 0.69 & 0.84 & 0.38 & 0.52 & 0.38 & 0.85 & 0.37 & 0.38 & 0.36 & 0.69 & 0.12 & 0.52 & 0.36 & 0.47 & 0.16 & 0.37 \\
\hline \multirow{2}{*}{ III } & $5.9 \pm$ & $12.28 \pm$ & $4.5 \pm$ & $7.43 \pm$ & $5.7 \pm$ & $8.2 \pm$ & $4.1 \pm$ & $5.35 \pm$ & $6.8 \pm$ & $10.21 \pm$ & $4.7 \pm$ & $8.55 \pm$ & $5.4 \pm$ & $7.18 \pm$ & $3.9 \pm$ & $6.06 \pm$ \\
\hline & 0.53 & 1.47 & 0.52 & 0.82 & 0.51 & 0.9 & 0.5 & 0.51 & 0.67 & 1.43 & 0.52 & 1.02 & 0.48 & 0.84 & 0.38 & 0.65 \\
\hline
\end{tabular}




\section{DISCUSSION}

The aim of these experiments was to monitor biogas production and composition, and to measure the processing parameters that characterize the anaerobic process $\left(\mathrm{pH}, \mathrm{VFA}\right.$, and $\left.\mathrm{NH}_{3}-\mathrm{N}\right)$. For anaerobic systems, these parameters are indicative, and a change in one parameter will cause change in others (Lazor et al., 2010; Magbanua et al., 2001).

To evaluate biogas production, it is necessary to know the concrete content of organic matter and its composition. This can be determined by several methods, but the most used is the measurement of VS that give the content of organic matter. The theoretical maximum yield per gram of VS depends on the type of organic matter, carbohydrate, proteins, lipids and VFA (Angelidaki and Ellegaard, 2003). Tables 1 illustrate the contents of VS, carbohydrate, proteins and lipids of AWS. The results clearly indicate that AWS have higher energy content, which makes them suitable as a co-substrate; this result was compatible with that obtained in previous studies (ElMashad and Zhang). Both manure and AWS contained well-balanced nutrients for anaerobic microorganisms. Results of $\mathrm{pH}$ tests showed that initial $\mathrm{pH}$ value of AWS is 4.85 , while by mixing $\mathrm{PM}$ and $\mathrm{AWS}$, the resulting mixture $\mathrm{pH}$ (ranged from 7.3-8) becomes more suitable for fermentation than with either substrate alone.

Manure is excellent as a "carrier" substrate to allow anaerobic digestion of other kinds of wastes, which would be difficult to treat separately. There are several reasons for this suitability, including the fact that the high buffering capacity contained in manure protects the process against failure owing to drop in $\mathrm{pH}$ in case of temporary VFA accumulation [41]. So the mixing of wastes produces a more suitable $\mathrm{pH}$ for anaerobic digestion.

Dry anaerobic fermentation of PM has usually encountered problems with methane inhibition as a result of ammonia accumulation. Improvement of dry anaerobic fermentation of PM had previously studied (Abouelenien et al., 2009 a, b; 2010) through either acclimatization or ammonia stripping technology. Here, we investigated improvement of dry fermentation of PM through co-digestion with AWS.

Methane production was a crucial indicator of the success or fail of the process. In Exp 1, highest methane production was $406 \mathrm{ml} \mathrm{g} \mathrm{V}^{-1}$ obtained from $\mathrm{M} 1$ at $35{ }^{\circ} \mathrm{C}$. This higher methane was attributed mainly to the addition of AWS, which resulted in a $195 \%$ increase in methane production compared with PM control (Fig 1[a]). The enhanced methane production resulted from a decrease in ammonia accumulation-by about 52\% compared with PM control (table 6). In turn, the decrease in ammonia accumulation resulted in complete degradation of
VFA (100\% of acetate produced was degraded to methane), keeping $\mathrm{pH}$ within the range of 8.1-8.8 (table 5), compatible with the normal growth of anaerobic microorganisms (Raposo et al., 2009). Methane production from M1 at $55{ }^{\circ} \mathrm{C}$ showed lower methane production of $324 \mathrm{ml} \mathrm{g} \mathrm{VS}^{-1}$ than under similar mesophilic condition (Fig 1[a]). However, even this amount was $151 \%$ higher than the PM control at the same temperature; there was a $43.7 \%$ decrease in ammonia accumulation in $\mathrm{M} 1$ at $55^{\circ} \mathrm{C}$ compared to PM control. It was observed that acetate was accumulated in the third batch with both M1 and PM control at $55{ }^{\circ} \mathrm{C}$, and with PM control at $35{ }^{\circ} \mathrm{C}$; this was then responsible for the inhibition of methane production (table 5). In spite of acetate accumulation, no drop in $\mathrm{pH}$ was observed; this may be explained by the buffering action of high ammonia accumulated under PM control (table 5).

In Exp 2, highest methane production was $562 \mathrm{ml} \mathrm{g}^{-1}$ VS obtained from M2 under the mesophilic condition. This higher methane was attributed mainly to the addition of AWS, which resulted in a $63 \%$ increase in methane production compared with TPM control at $35{ }^{\circ} \mathrm{C}$ table 5. Enhanced methane production resulted from lower ammonia accumulation than control (by $35 \%$ compared to TPM control; table 6). The amount of methane produced from M2 under the mesophilic condition was $38.4 \%$ higher than that obtained from M1 under the same condition. This may be attributed to lower ammonia accumulation with M2 (3.9, compared with $4.1 \mathrm{~g} \mathrm{~N} \mathrm{~kg}^{-1}$ bed from M1).

At $55{ }^{\circ} \mathrm{C}$, M2 showed lower methane production of $298 \mathrm{ml} \mathrm{g}^{-1} \mathrm{VS}$ than $\mathrm{M} 2$ at $35^{\circ} \mathrm{C}$, but was higher than that produced from the M2 control (Fig 1[b]). Complete inhibition of methane production was observed in the third batch of TPM control and M2 at $55^{\circ} \mathrm{C}$ (Fig 1[b]); this can be explained by the acetate accumulation that occurred concurrently with ammonia accumulation (tables 4 and 6).

In all experiments, methane percentage ranged from $58-70 \%$ of biogas produced, which is nearly the same as previously reported (Apples et al., 2008; Bujoczek et al., 2000). The addition of AWS to PM resulted in an increase in the methane fraction of biogas compared with control with no AWS added (data not shown). This result is incompatible with that obtained by Borowski and Weatherley (2013), who reported that addition of poultry manure to the sludge had no impact either on methane content or on the amount of trace gases, even though they reported nearly the same range of $66 \%-68 \%$.

The superior biogas production and methane yields of M1 and M2 compared to the control demonstrate that co-digestion of PM or TPM and AWS using high TS\% (20\%) is available and results in a synergistic effect (Magbanua et al., 2001, Wang et al., 2012, Yangin-Gomec and Ozturk, 2013). Our results proved 
better performance of co- digestion under mesophilic conditions than under thermophilic conditions, which may be attributed to less ammonia accumulation under the mesophilic (about a 29\% decrease in ammonia accumulation in both $\mathrm{M} 1$ and $\mathrm{M} 2$ test) (table 6) (Abouelenien et al., 2009a, Gallert and winter 1997, Yangin-Gomec and Ozturk, 2013). Accumulation of acetate was under the thermophilic condition, resulting in complete cessation of methane production. Acetate accumulation under the thermophilic condition was the limiting factor leading to both a decrease in $\mathrm{pH}$ and accumulation of ammonia, which combined to make ammonium acetate that consequently inhibit methane production (Abouelenien et al., 2010; Kim et al., 2002). In the 2nd batch, the PM control showed accumulation of VFA (especially acetate) above the threshold limit without cessation in methane production, as $\mathrm{pH}$, at 8.7, was high enough to inhibit the toxicity of VFA (Apples et al., 2008; Borowski and Weatherley, 2013; Bujoczek et al., 2000).

Our present result was better than that obtained by Ahn et al. (2010), who found that co-digestion of switch grass-poultry manure mixture resulted in slow production of VFA, as well as the accumulation of it, which resulted from minimal conversion of VFAs to $\mathrm{CH}_{4}$ by methanogens. They added that the accumulated VFAs resulted in irreversible digester acidification and the low $\mathrm{pH}$ inhibited methanogens from converting VFAs to methane. As no significant drop in $\mathrm{pH}$ was observed in our results, this proved that ammonia and acetate accumulation together were likely the limiting factor, rather than the $\mathrm{pH}$ drop.

Magbauna et al. (2001) obtained similar results from co-digestion of hog and poultry waste They obtained a fixed $\mathrm{pH}$ range of $7 \pm 0.5$ to $7.5 \pm 0.5$, which is optimum for methanogenesis. But in contrast to our results, when they used poultry manure alone, $\mathrm{pH}$ dropped over the first $15-20$ days, to as low as $4.5 \pm$ 0.5 .

Dry anaerobic fermentation of PM under thermophilic conditions often encounters very high concentrations of ammonia due to extensive hydrolysis of nitrogen compounds, and the inhibitory effect of ammonia on thermophilic methanogens (Gallert and winter, 1997, Kim et al., 2002, Ahn et al., 2010) becomes significant. We obtained higher ammonia accumulation at PM and TPM control at 55 ${ }^{\circ} \mathrm{C}$ (12.28 and $10.2 \mathrm{~g} \mathrm{~N} / \mathrm{kg}-1 \mathrm{bed}$; table 6), which caused inhibition of methane production. Mixing of AWS with PM or TPM resulted in lower accumulated ammonia (ranging from 5.35 to $8.55 \mathrm{~g} \mathrm{~N} / \mathrm{kg}^{-1}$ bed), which allowed methane production despite an ammonia level higher than the threshold one. This result is different from that obtained by Sung and Liu, (2003), who observed that total ammonia nitrogen (TAN) concentration of 4.92 and $5.77 \mathrm{~g} \mathrm{~L}^{-1}$ decreased the production of methane by $39 \%$ and $64 \%$, respectively. Moreover, Sung and Liu, (2003) reported $100 \%$ inhibition in the range of $8-13 \mathrm{~g} \mathrm{~L}^{-1}$, depending on the condition of acclimatization and the $\mathrm{pH}$ of the system.

The amount of methane produced in these experiments was higher than that obtained in previous studies (Abouelenien et al., 2009a, b; 2010). Levels of $562 \mathrm{mlg}^{-1} \mathrm{VS}$ and $406 \mathrm{mlg}^{-1} \mathrm{VS}$ were the highest amount of methane produced from M1 and M2 under $35{ }^{\circ} \mathrm{C}$ respectively. Abouelenien et al. (Abouelenien et al., 2009a) studying dry anaerobic fermentation of PM (25\% TS) under mesophilic conditions, obtained 4.4 $\mathrm{LKg}^{-1} \mathrm{PM}-\mathrm{DW}$ (31 ml g-1VS) after 254 days. In another study, Abouelenien et al. (2009 b] reported a

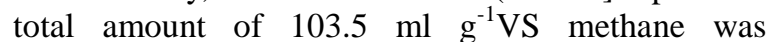
produced from twice ammonia stripped PM after 55 days of fermentation under $55^{\circ} \mathrm{C}$. Simultaneous ammonia striping and methane fermentation of PM using a bench scale reactor under thermophilic conditions resulted in $194.5 \mathrm{ml} \mathrm{g}^{-1} \mathrm{VS}$ and $157.2 \mathrm{ml} \mathrm{g}^{-}$ ${ }^{1} \mathrm{VS}$ of methane obtained from TPM and mixture of TPM: PM (1:1) respectively (Abouelenien et al., 2010).

Additionally we obtained higher methane production than that obtained by Chen et al. (2012), who reported $107.25 \mathrm{ml} \mathrm{g}^{-1} \mathrm{TS}$ of biogas (76.92\% methane) was produced from co-digestion of PM with spartina alterniflora residues (SAR) at $35{ }^{\circ} \mathrm{C}$ with initial TS of $8 \%$. Ahn et al. (2010) found that anaerobic digestion of poultry manure-switch grass mixture under $15 \%$ TS and thermophilic conditions $\left(55^{\circ} \mathrm{C}\right)$ resulted in very poor methane yield of $2 \mathrm{ml} \mathrm{g}^{-}$ ${ }^{1} \mathrm{VS}$ after 62 days digestion. They attributed this poor methane yield to VFA accumulation and $\mathrm{pH}$ drop.

Magbanua et al. (2001) tried co-digestion of hog and poultry waste in various proportions (poultry manure TS was $1.74 \%$; digestion temperature was $35 \pm 2$ ). They found that treatments that received both wastes produced higher yields of biogas; however, they obtained lower methane production of $130 \pm 20 \mathrm{ml} \mathrm{g}^{-}$ ${ }^{1} \mathrm{VS}$ than that found in the current experiment. The co-digestion process of PM (PM and TPM) and AWS under dry condition (TS 20\%) resulted in great enhancement of methane production. Results of ammonia accumulation $\left(5.35-12.28 \mathrm{~N} \mathrm{~g}^{-1} \mathrm{~kg}\right.$ bed $)$ indicated that co-digestion of PM with AWS increased ammonia tolerance of methanogenesis and allowed methane to be successfully produced.

\section{CONCLUSION}

Dry co-digestion of PM or TPM and AWS (TS\% of 20) performed better than individual digestion because of lower ammonia accumulation and better degradation of VFA. Mixtures of PM or TPM and AWS in co-digestion presented higher synergetic effect than digestion of single manure. Comparing thermophilic and mesophilic co-digestion conditions, 
better performance was achieved under the mesophilic condition. Optimum methane production of $562 \mathrm{mlg}^{-1} \mathrm{VS}$ was obtained under the mesophilic, and this amount is the highest volume achieved so far. Ammonia accumulation is reduced by $43.7 \%$ during the test experiments compare to the control.

\section{ACKNOWLEDGEMENTS}

The authors are grateful to Hitachi Engineering and Serves (HES), Japan for financial support.

\section{REFERENCES}

Abouelenien, F.; Namba, Y.; Kosseva, M.; Nishio, N. and Nakashimada, Y. (2014): Enhancement of methane production from co digestion of chicken manure with agricultural wastes. Bioresour Technol 159: 80-87.

Abouelenien, F.; Fujiwara, W.; Namba, Y.; Kosseva, M.; Nishio, N. and Nakashimada, Y. (2010): Improved methane fermentation of chicken manure via ammonia removal by biogas recycle. Bioresour Technol 101: 6368-6373.

Abouelenien, F.; Kitamura, Y.; Nishio, N. and Nakashimada, Y. (2009a): Dry anaerobic ammonia-methane production from chicken manure. Appl Microbiol Biotechnol; 82: 757764.

Abouelenien, F.; Nakashimada, Y. and Nishio, N. (2009b): Dry mesophilic fermentation of chicken manure for production of methane by repeated batch culture. J. Biosci Bioeng 107: 293-295.

Ahn, HK.; Smith, MC.; Kondrad, S.L. and White, JW. (2010): Evaluation of biogas production potential by dry anaerobic digestion of switch grass-animal manure mixture. Appl Biochem Biotech; 160: 965-975.

Alvarez, R. and Liden, G. (2007): The effect of temperature variation on biomethanation at high altitude. Bioresour Technol 99: 72787284.

Angelidaki, I. and Ellegaard, L. (2003): Co digestion of manure and organic wastes in centralized biogasplants status and future trends Appl Biochem Biotechnol 109: 95-105.

AOAC (1995): Official method of analysis. 16th ed. Virginia: Association of Official Agricultural Chemists; 1995.

APHA (1998): Standard methods for the examination of water and wastewater, 20th ed. APHA, AWWA, WEF, Washington, DC.

Apples, L.; Baeyens, J.; Degrève, J. and Dewil, R. (2008): Principles and potential of the anaerobic digestion of waste-activated sludge. Prog Energ Combust; 34: 755-781.

Borowski, S. and Weatherley, L. (2013): Co-digestion of solid poultry manure with municipal sewage sludge. Bioresour Technol 142: 345352.
Brown, D. and Li, Y. (2013): Solid state anaerobic codigestion of yard waste and food waste for biogas production. Bioresour Technol. 127, 275-280.

Brown, D.; Shi, J. and Li, Y. (2012): Comparison of solid-state to liquid anaerobic digestion of lignocellulosic feedstocks for biogas production. Bioresour Technol. 124, 379-386

Bruni, E.; Ward, AG,; Kфcks, M.; Anders Feilberg, A.; Adamsen, A.P.S.; Jensen, A.P.; Allan, K. and Poulsen, A.K. Comprehensive monitoring of a biogas process during pulse loads with ammonia. Biomass Bioenergy. 56, 211-220.

Bujoczek, G.; Oleszkiewicz, J.; Sparling, R. and Cenkowski, S. (2000): High solid anaerobic digestion of chicken manure. J. Agric Eng Res; 76: 51-60.

Callaghan, FJ.; Wase, DAJ.; Thayanithy, K. and Forster, CF. (2002): Continuous co-digestion of cattle slurry with fruit and vegetable wastes and chicken manure. Biomass Bioenergy. 27, 71-77

Calli, B.; Mertoglu, B.; Inanc, B. and Yenigun, O. (2005): Effect of high free ammonia concentrations on the performances of anaerobic bioreactors. Process. Biochem. 40, 1285-1292.

Chen, G.Y.; Chang, Z.Z.; Ye, X.M.; Du. J.; Xu, Y.D. and Zhang, JY. (2012): Methane production by anaerobic co-digestion of chicken manure and Spartina alterniflora residue after producing methane Huan Jing Ke Xue. 33, 203-7.

Corro, G.; Paniagua, L.; Pal, U.; Bañuelos, F. and Rosas, M. (2013): Generation of biogas from coffee-pulp and cow-dung co-digestion: Infrared studies of postcombustion emissions. Energ. Convers. Manage. 74, 471-481.

Demirci, GG. and Demirer, GN. (2004): Effect of initial COD concentration, nutrient addition, temperature and microbial acclimation on anaerobic treatability of broiler and cattle manure. Bioresour. Technol. 93, 109-117

Dong, X. and Tollner, EW. (2003): Evaluation of Anammox and denitrification during anaerobic digestion of poultry manure. Bioresour. Technol. 86, 139-145.

Dubois, M.; Gilles, KA.; Hamilton, JK.; Rebers, PA. Smith, F. (1956): Colorimetric method for determination of sugar and related substance. Anal. Chem. 28, 350-356.

El-Mashad, HM. and Zhang, R. (2010): Biogas production from co-digestion of dairy manure and food waste. Bioresour. Technol. 101, 4021-4028.

Esposito, G.; Frunzo, L.; Liotta, F.; Antonio Panico, A. and Pirozzi, F. (2012): Bio-Methane potential tests to measure the biogas production from the digestion and codigestion of complex organic substrates. Open. 
Environ. Eng. J. 5, 1-8.

Forster-Carneiro, T.; Pérez García, M.; Romero García, LI. and Sales, D. (2007): Dry thermophilic digestion of organic fraction of the municipal solid waste: focusing on the inoculum sources. Bioresour. Technol. 98, 3195-3203.

Gallert, C. and Winter, J. (1997): Mesophilic and thermophilic anaerobic digestion of sourcesorted organic waste: Effect of ammonia on glucose degradation and methane production. Appl. Microbiol. Biotechnol. 48, 405-410.

Karaalp, D.; Calıskan, G. and Azbar, N. (2013): Performance evaluation of a biogas reactor Processing Chicken Manure with High Solids Content Digital Proceeding Of THE ICOEST'2013-, Cappadocia C. Nevsehir, Turkey, June $18-21,2013$.

Khalid, A.; Arshad, M.; Anjum, M.; Mahmood, T. and Dawson, L. (2011): The anaerobic digestion of solid organic waste. Waste. Manage. 31, 1737-1744.

Kim, M.; Ahn, Y. and Speece, RE. (2002): Comparative process stability and efficiency of anaerobic digestion; mesophilic vs. thermophilic. Water Research; 4369-4385.

Krylova, NI.; Khabiboulline, RE.; Naumova, RP. and Nagel, MA. (1997): The influence of ammonia and methods for removal during the anaerobic treatment of poultry manure. J. Chem Tech Biotechnol; 70: 99-105.

Lazor, M, Huťnan, M.; Sedlácek, S.; Kolesárová, N. and Špalková, V. (2010): Anaerobic codigestion of poultry manure and waste kitchen oil, Editor: Markoš, J., In Proceedings of the 37th International Conference of Slovak Society of Chemical Engineering, Tatranské Matliare, Slovakia, 1399-1406. (37th International Conference of SSCHE May 2428, Tatransk'e Matliare, Slovakia.

Li, Y.; Park, SY. and Zhu, J. (2011): Solid-state anaerobic digestion for methane production from organic waste. Renew Sust Energ Rev. $15,821-826$.

Li, Y.; Zhang, R.; Chen, C.; Liu, G.; He, Y. and Liu, X. (2013): Biogas production from co-digestion of corn stover and chicken manure under anaerobic wet, hemi-solid, and solid state conditions. Bioresour Technol. 149, 406-412.

Lowry, OH.; Rosebrough, NJ.; Farr, AL. and Randall, RJ. (1951): Protein measurement with the Folin phenol reagent. J. Biolog Chem; 193: 265- 275.

Magbanua, BS.; Adams, TT. and Johnston, P. (2001): Anaerobic co-digestion of hog and poultry waste. Bioresour Technol 76: 165-168.

Nishio, N. and Nakashimada, Y. (2007): Recent development of anaerobic digestion processes for recovery of energy from wastes. J. Biosci
Bioeng; 103: 105-112.

Panichnumsin, P.; Noppharatana, A.; Ahring, BK. and Chaiprasert, P. (2010): Production of methane by co-digestion of cassava pulp with various concentrations of pig manure. Biomass Bioenerg 34: 1117-1124.

Ragauskas, AJ.; Williams, CK.; Davison, BH.; Britovsek, G.; Cairney, J.; Eckert, CA.; Frederick, Jr,WJ,3 Jason, P.; Hallett, JP.; Leak, DJ. and Liotta, CL. (2006): The Path Forward for Biofuels and Biomaterials. Science 311 (5760), 484-489.

Raposo, F.; Borja, R.; Martin Santos, MA.; Martin, A.; de la Rubia, MA. and Rincon, B. (2009): Influence of inoculum-substrate ratio on the anaerobic digestion of sunflower oil cake in batch mode: process stability and kinetic evaluation. Chem Eng J 149: 70-77.

Schafer, W.; Lehto, M. and Teye, F. (2006): Dry anaerobic digestion of organic residues onfarm-a feasibility study. MTT Agrifood Research Reports 77. Agricultural Engineering; Finland. <http://www.mtt.fi/met/ pdf/met77.pdf>.

Sung, S. and Liu, T. (2003.): Ammonia inhibition on thermophilic anaerobic digestion. Chemosphere 53: 43-52.

Wall, DM.; Wu-Haan, W. and Safferman, S.I. (2012): Reconstitution of dewatered food processing residuals with manure to increase energy production from anaerobic digestion. Biomass and bioenergy.; 4 6: 429- 434.

Wang, X.; Yang, G.; Feng, Y.; Ren, G. and Han, X. (2012): Optimizing feeding composition and carbon-nitrogen ratios for improved methane yield during anaerobic co-digestion of dairy, chicken manure and wheat straw. Bioresour Technol 120: 78-83.

Wang, X.; Yang, G.; Li, F.; Feng, Y. and Ren, G. (2013): Response surface optimization of methane potentials in anaerobic co-digestion of multiple substrates: dairy, chicken manure and wheat. Waste Manag Res 31: 60-6.

$X u, F$. and $L i, Y$. (2012): Solid-state co-digestion of expired dog food and corn stover for methane production. Bioresour Technol. 118: 219-226.

Yangin-Gomec, C. and Ozturk, I. (2013): Effect of maize silage addition on biomethane recovery from mesophilic co-digestion of chicken and cattle manure to suppress ammonia inhibition. Energ Convers Manage 71:92-100.

Zhou, Y.; Zhang, Z.; Tomoko Nakamoto, T.; Li, Y.; Yang, Y.; Utsumi, M. and Sugiura, N. (2011): Influence of substrate-to-inoculum ratio on the batch anaerobic digestion of bean curd refuseokara under mesophilic conditions. Biomass Bioenergy. 35, 3251-3256. 


\section{معالجة روث الاواجن باستخدام خليط من مخلفات القهوة والكسافا وجوز الهند \\ فاطمه ابو العبنين ، ناكاشبيادا بيوتاكا}

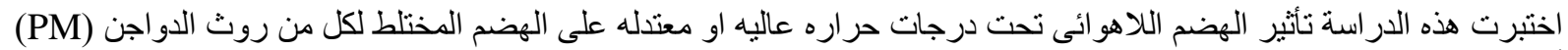

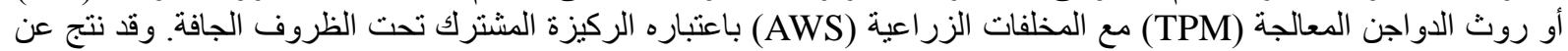

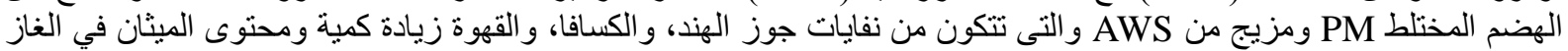

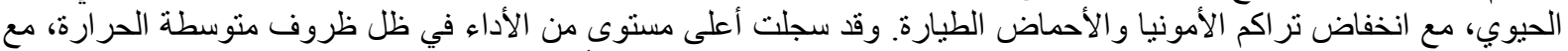

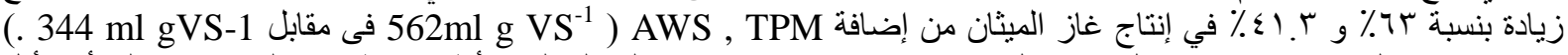

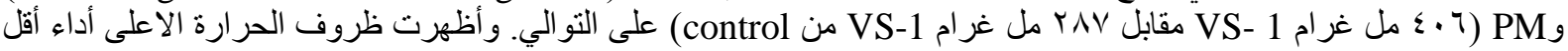

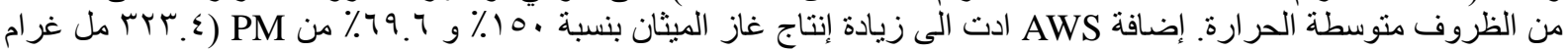

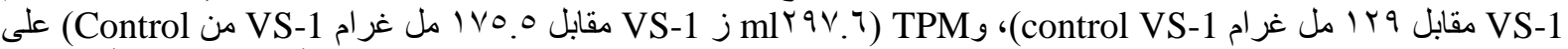

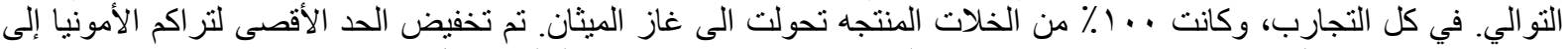

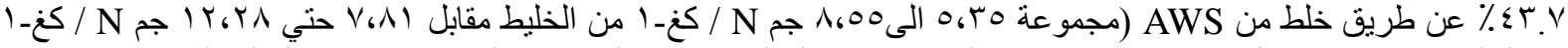

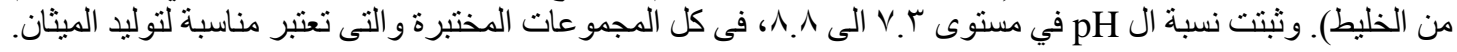

